\title{
Identification of Constraints Associated with Farmers' Producer Organisations (FPOs)
}

\author{
Jitendra Kumar Chauhan ${ }^{1 *}$, Ankur Adhikary ${ }^{2}$ and K. Pradhan ${ }^{2}$ \\ ${ }^{1}$ College of Post Graduate Studies in Agricultural Sciences, Umiam, Meghalaya (CAU), \\ Imphal, Manipur, India \\ ${ }^{2}$ Department of Agricultural Extension, Uttar Banga Krishi Viswavidyalaya, \\ Pundibari, Coochbehar, WB, India \\ *Corresponding author
}

A B S T R A C T

Keywords

Farmers' Producers Organisation (FPO), Technical constraint, Labour constraint, Economic constraint, Marketing constraint, Organisational constraint

Article Info

Accepted: 12 December 2020 Available Online: 10 January 2021
In the era of globalisation and free trade liberalisation, the concept of collectivisation or group initiation through local level organisation is very essential. Farmer Producer Organizations, principally using the concept of collectivisation offer small farmers to participate in the market more effectively and collectively, they are in a better position to reduce transaction costs of accessing inputs and outputs, obtaining the necessary market information, securing access to new technologies and allowing them to compete with larger farmers and agribusinesses. Keeping these in view the present study was conducted to identify the constraints associated with the functioning of Farmers' Producers Organisation (FPO) to run this organisation smoothly by developing some coping strategies. The present study was conducted in Cooch BeharI, Cooch Behar-II, Dinhata-I, Dinhata-II, Tufanganj-I, Tufanganj-II blocks of Cooch Behar district in West Bengal. Purposive and random sampling techniques were followed in case of selecting the area and the respondents of the present study. Data collection was done by structured interview schedule after pre-testing with the help of personal interview method. The Rank Based Quotient (RBQ) method was used to analyse the data and draw conclusion. The constraints were categorised into technical constraint, labour and economic constraint, marketing constraint and organisational constraints.

\section{Introduction}

In the era of globalisation and free trade liberalisation, the need of the hour is to transform the mere producer of agricultural product to producer cum seller of the produce through developing rural entrepreneurship by applying the concept of collectivisation or group initiation through local level organisation. As a consequence of globalisation and climate change, an appropriate technology transfer mechanism is needed to enhance sustainable food production and marketing for income 
enhancement. Doubling farmers' income requires combined approach of improved technology, practices, processing, marketing and entrepreneurship development. Agriculture has always been a lifeline of the Indian economy, providing livelihood to millions of farmers. The government intervention was required to create a policy environment that would ensure a mutually beneficial relationship between the farmers and organized sector (Mittal, 2007). Therefore, a need was felt in developing effective technology delivery system which can fulfil the specific need of small and marginal farmers. The focus of the hour should be on to increase the profitability of the Indian farmers. The efficacy of appropriate extension delivery system can only be the panacea to uplift the income status of the pro-poor farmers of our society through applying the concept of market led extension and developing agri-preneurship by group action which can be achieved through an effective grass root level organisation like farmers' producer organisation. Farmer organizations can increase the access of small producers to new technology, market information and business services in rural areas that contributed to productivity, growth and intensification and commercialization of smallholder agriculture, thereby increasing their incomes (Shiferaw et al., 2016). The farmers' producer organizations and producer companies were very much beneficial to improve the value chain of agricultural produce and thereby proved to be in getting good prices for their produce (Sawairam, 2014).

In such a potential perspective of Farmers' Producers Organisation the present study is very much relevant to isolate the constraints associated with the functioning of FPOs and develop some coping strategies for smooth functioning of FPOs.

\section{Materials and Methods}

The present study was conducted in Cooch Behar district in West Bengal which was purposively selected. The purposive, multistage and random sampling techniques were followed in case of selecting the area and the respondents of the present study. The Cooch Behar block-I, Cooch Behar block-II, Dinhata block-I, Dinhata block- II, Tufanganj block- I, Tufanganj block- II from the selected district were also selected with the help of simple random sampling procedure. From Cooch Behar block-I five (5) Farmers' Producer Organisations (FPOs), from Cooch Behar block-II five (5) FPOs, from Dinhata block-I one (1) FPO, from Dinhata block- II four (4) FPOs, from Tufanganj block- I four (4) FPOs, from Tufanganj block- II one (1) FPO were selected purposively for the present study due to their success in enterprise development, sustainability and extension delivery. From each FPO, 5 members and or office bearers (respondents) were selected randomly among the twenty (20) numbers of office bearers or governing body members. In this way, the total one hundred (100) FPO members and or office bearers in the study area constituted the sample for this study. The data were collected with the help of pre-tested structured interview schedule through personal interview method. The data were processed into Rank Based Quotient (RBQ) method to draw a definite conclusion.

\section{Results and Discussion}

The following constraints associated with the functioning of FPOs were categorised and presented below:

Table 1 depicts the technical constraints of Farmers' Producer Organizations (FPOs) in the study area selected through nine statements. 
The first constraint associated with technical constraints faced by the FPO members and/or office bearers is undeveloped storage facilities. The challenge related to undeveloped storage facilities is that most of the FPO's are formed recently and it is very challenging for any new organization to build all the infrastructure so quickly.

The second constraint associated with technical constraints faced by the FPO members and/or office bearers is undeveloped processing facilities. The challenge related to undeveloped processing facilities is that a processing unit is very costly and it is very difficult for newly formed FPOs to set up a well developed infrastructure within a year.

The third constraint associated with technical constraints faced by the FPO members and/or office bearers is lack of Computer knowledge which makes them unable to derive benefits of the available ICT tools. Lack of awareness about packaging is also a major constraint for the FPO members and/or office bearers. The members are not well aware about packaging of processed product. The other constraints perceived by the FPO members and/or office bearers which have a great role to make the obstacles in case of growth, development and management of FPO according to their priority are lack of proper infrastructures (implements, irrigation facilities, power and electricity), lack of timely, cheap and good quality inputs, lack of proper practices, high incidence of diseases and pests, crop failure. All these constraints need special consideration and a strategy to be made to cope these challenges and placed before the planners and policy makers for their solutions.

Table 2 depicts the labour and economic constraints of Farmers' Producer Organizations (FPOs) in the study area selected through seven statements.
The first constraint associated with labour and economic constraints faced by the FPO members and/or office bearers is lack of labour available during harvesting.

The second constraint associated with labour and economic constraints faced by the FPO members and/or office bearers is lack of sufficient finance. The challenge related to lack of sufficient finance is that an initial investment is necessary to set up and run a newly formed FPO.

Lack of skilled labourers in harvesting, processing, is also a major constraint for the FPO members and/or office bearers. The other constraints perceived by the FPO members and/or office bearers which have a great role to make the obstacles in case of growth, development and management of FPO according to their priority are high cost of labour during harvesting, lack of proper crop insurance facilities, lack of proper government price policy, lack of awareness of credit facilities.

All these constraints need special consideration and a strategy to be made to cope these challenges and placed before the planners and policy makers for their solutions.

Table 3 depicts the marketing constraints of Farmers' Producer Organizations (FPOs) in the study area selected through seven statements.

The first constraint associated with marketing constraints faced by the FPO members and/or office bearers is fluctuation of price in every year.

The second constraint associated with marketing constraints faced by the FPO members and/or office bearers is lack of proper market information. 
Table.1 Technical Constraints of FPOs

\begin{tabular}{|l|l|c|c|}
\hline $\begin{array}{c}\text { SI. } \\
\text { No. }\end{array}$ & \multicolumn{1}{|c|}{ Statement } & RBQ & Rank \\
\hline $\mathbf{1 .}$ & Lack of timely, cheap and good quality inputs & 49.44 & $6^{\text {th }}$ \\
\hline 2. & $\begin{array}{l}\text { Lack of proper infrastructures (implements, irrigation } \\
\text { facilities, power and electricity) }\end{array}$ & 51.00 & $5^{\text {th }}$ \\
\hline 3. & Undeveloped storage facilities & 98.89 & $1^{\text {st }}$ \\
\hline 4. & Undeveloped processing facilities & 89.67 & $2^{\text {nd }}$ \\
\hline $\mathbf{5 .}$ & Lack of proper practices & 32.67 & $7^{\text {th }}$ \\
\hline 6. & High incidence of diseases and pests & 26.34 & $8^{\text {th }}$ \\
\hline 7. & Crop failure & 12.34 & $9^{\text {th }}$ \\
\hline 8. & $\begin{array}{l}\text { Lack of Computer knowledge which makes them unable to } \\
\text { derive benefits of the available ICT tools }\end{array}$ & 72.89 & $3^{\text {rd }}$ \\
\hline 9. & Lack of awareness about packaging & 71.22 & $4^{\text {th }}$ \\
\hline & & & \\
\hline
\end{tabular}

Table.2 Labour and economic constraints of FPOs

\begin{tabular}{|l|l|l|c|}
\hline SI. No. & \multicolumn{1}{|c|}{ Statement } & RBQ & Rank \\
\hline 1. & Lack of labour available during harvesting & 99.71 & $1^{\text {st }}$ \\
\hline 2. & Lack of skilled labourers in harvesting, processing & 57.44 & $3^{\text {rd }}$ \\
\hline 3. & Lack of proper crop insurance facilities & 28.72 & $5^{\text {th }}$ \\
\hline 4. & Lack of sufficient finance & 69.14 & $2^{\text {nd }}$ \\
\hline $\mathbf{5 .}$ & Lack of awareness of credit facilities & 16.15 & $7^{\text {th }}$ \\
\hline 6. & High cost of labour during harvesting & 32.99 & $4^{\text {th }}$ \\
\hline 7. & Lack of proper government price policy & 19.13 & $6^{\text {th }}$ \\
\hline
\end{tabular}

Table.3 Marketing constraints of FPOs

\begin{tabular}{|l|l|c|c|}
\hline Sl. No. & \multicolumn{1}{|c|}{ Statement } & RBQ & Rank \\
\hline 1. & Fluctuation of price in every year & 96.14 & $1^{\text {st }}$ \\
\hline $\mathbf{2 .}$ & Lack of proper market information & 87.29 & $2^{\text {nd }}$ \\
\hline 3. & Low price of produce & 59.85 & $4^{\text {th }}$ \\
\hline 4. & High cost of transportation & 44 & $5^{\text {th }}$ \\
\hline $\mathbf{5 .}$ & Involvement of middle men & 67 & $3^{\text {rd }}$ \\
\hline 6. & Nature of products ( perishablility ) & 23.43 & $6^{\text {th }}$ \\
\hline 7. & Delayed payment & 19.86 & $7^{\text {th }}$ \\
\hline
\end{tabular}

Table.4 Organizational constraints of FPOs

\begin{tabular}{|l|l|c|c|}
\hline Sl. No. & \multicolumn{1}{|c|}{ Statement } & RBQ & Rank \\
\hline 1. & Lack of connection with financial organizations & 77 & $2^{\text {nd }}$ \\
\hline 2. & Lack of proper infrastructure & 89.67 & $1^{\text {st }}$ \\
\hline 3. & Lack of proper decision making ability & 33.33 & $3^{\text {rd }}$ \\
\hline
\end{tabular}


Involvement of middleman is also a major constraint for the FPO members and/or office bearers. The other constraints perceived by the FPO members and/or office bearers which have a great role to make the obstacles in case of growth, development and management of FPO according to their priority are low price of produce, high cost of transportation, nature of products (perishablility), delayed payment. All these constraints need special consideration and a strategy to be made to cope these challenges and placed before the planners and policy makers for their solutions.

Table 4 depicts the organizational constraints of Farmers' Producer Organizations (FPOs) in the study area selected through three statements.

The first constraint associated with organizational constraints faced by the FPO members and/or office bearers is lack of proper infrastructure.

The second constraint associated with organizational constraints faced by the FPO members and/or office bearers is lack of connection with financial organizations.

Lack of proper decision making ability, is also a major constraint for the FPO members and/or office bearers. All these constraints need special consideration and a strategy to be made to cope these challenges and placed before the planners and policy makers for their solutions.

In conclusion as a consequence of globalisation and climate change, an appropriate technology transfer mechanism is needed to enhance sustainable food production and marketing for income enhancement and also Central Government emphasises on doubling farmers' income with an objective to help the farmers to come out from poverty and lead a good life. Doubling farmers' income requires combined approach of improved technology, practices, processing, marketing and entrepreneurship development. Agriculture has always been a lifeline of the Indian economy, providing livelihood to millions of farmers. It is the main occupation of the majority of population of India and act as the backbone of Indian economy. To overcome the challenges there are various alternatives but one of the potential alternative for efficient farming, information sharing, delivery of inputs, marketing and profit making is mobilizing farmers for group action through developing farmer's organizations which are the integral component of delivery system to take collective decisions for income enhancement through agricultural development at the local level.

The challenges associated with FPO are very definite and complex in nature which needs immediate intervention from the policy makers and planners to cope the challenges for sustaining the existing FPOs towards economic development of the rural poor. Some of the issues related to FPO in technical, marketing, organisational, social aspect needs strategic interventions to make the existing FPOs more vibrant, sustainable and profitable, situation and location specific, extension oriented towards income enhancement of the farming community.

The following strategies may be taken into consideration for scaling up and scaling out of FPOs:

Strengthening the FPOs with adequate knowledge, infrastructure, technical backstopping of agriculture and agripreneurship should be accommodated

Appropriate capacity building method should be adopted to make FPO members and office bearers capable of making appropriate and timely decisions 
Appropriate linkage with the financial institutions and FPO should be strengthened to promote agri-enterprises establishment at a large scale.

Adequate skill embedded knowledge related to processing, value addition, storage of agricultural products and application of Information Communication Technology in marketing of produce should be provided.

Adequate market intelligence, market infrastructure and supply chain should be promoted for getting optimu

Policy should be developed to establish the FPOs as the grass root organisation of extension delivery mechanism for scaling out the agricultural and agrientrepreneurial knowledge to the common farmers.

\section{References}

Mittal, S. (2007) Strengthening backward and forward linkages in horticulture: some successful initiatives. Agricultural Economics Research Review. 2: 457460.

Sawairam, P. (2014) Case study on Farmer Producer Organization in Maharashtra in the era of globalization. IMRD's Journal of Management and Research. 4(2): 1-11.

Shiferaw, B., Hellin, J. and Muricho, G. (2016) Market access and agricultural productivity growth in developing countries: Challenges and opportunities for producer organizations. Economic Democratization. 1:103-124.

\section{How to cite this article:}

Jitendra Kumar Chauhan, Ankur Adhikary and Pradhan, K. 2021. Identification of Constraints Associated with Farmers' Producer Organisations (FPOs). Int.J.Curr.Microbiol.App.Sci. 10(01): 1859-1864. doi: https://doi.org/10.20546/ijcmas.2021.1001.217 